Article

\title{
The Tempests of Time, Rights, Race and Justice: Mandela and MLK Jr. as Transformational Leaders or Beneficiaries of Extraordinary Circumstances?
}

\author{
Stephen Magu
}

Pan African - Pan American Institute; Kenya Research Networks; stephen.magu@hamptonu.edu

\begin{abstract}
The Rev. Martin Luther King Jr. and Nelson Mandela were two of the world's most iconic civil (political) (human) rights advocates and leaders of all time. Both advocated for, and to varying degrees, applied elements of peaceful protests to the achievement of their goals. Both spent time in jail, often concurrently, but eventually forced their respective countries to extend the same rights that white populations had denied Africans and African Americans. For the US, civil rights, voting rights, right to education, housing and housing loans suggested that equality had been achieved, capped in South Africa by the election of Nelson Mandela as the first majority-rule president, and in the US, by Barack Obama's election to the presidency. Yet the historical over-policing, police mistreatment and more generally, the judicial system's inordinate 'targeting' of African Americans, with egregious cases running from Emmett Till to Rodney King to Walter Scott to Breonna Taylor to George Floyd to Rayshard Brooks and thousands of others shows the danger of such magical thinking. The now-persistent global wave pursuing human rights, civil rights and the right to be treated equally, primarily driven by the loosely-organized Black Lives Matter (BLM) movement, has become the leading voice in pursuit of equality. Riots such as those in LA, protests in Ferguson and everywhere in summer 2020 has ushered new civil rights campaign. In the US and elsewhere, it has morphed to include historical issues such as monuments to colonialism, the US civil war, slavery and slave owners and traders, institutions, companies and people whose wealth and existence has links to slavery. Instructively, the protests persisted even as COVID-19, the hundred-year plague, continues to ravage the world. Lost in the moment is the absence of central leadership and leaders such as MLK or Mandela. Their charisma and effectiveness has been lacking for 50 years. This paper evaluates whether this has led to inconsistent civil and human rights pursuit for equality, or whether perchance, Mandela and MLK were extraordinary, once-in-a-lifetime transformative leaders uniquely selected by history for their rime.
\end{abstract}

Keywords: Pan-Africanism; African Diaspora; liberation; transformational leadership; civil rights; colonialism; Martin Luther King Jr; Nelson Mandela

\section{Introduction}

Some notable $20^{\text {th }}$ and early $21^{\text {st }}$ century leaders gained recognition for leading their nations out of adversity - social, economic, political, even war - transitioning, stabilizing, preserving or creating new nations. Such leaders include Roosevelt, Truman, Churchill, Ben Gurion, Ho Chi Minh, Stalin, Mandela, Gandhi, Mao Zedong, Nasser, Tito, Kenyatta and Nkrumah. Some were wartime leaders, some notorious, some reviled, others revered. Some were recognized for individual sacrifices, others for standing fast, e.g. Churchill. The early 1960s saw global political headwinds, sweeping liberation of colonies and significant change that ushered in new nations; at the same time, across the Atlantic, a profound cultural transformation and the fight for equality was ongoing. In the U.S., conditions for African Americans - despite almost a century of post-slavery freedom - closely tracked conditions in African colonies, especially Rhodesia and apartheid South Africa. Perhaps in response to, or because of the singular viciousness of the discrimination in both countries, Nelson Mandela and the Rev. 
Martin Luther King Jr. became leaders, their fight for equality and freedom making them transformational leaders, icons and leaders, their rise as inevitable as it was necessary. 1960s saw the imprisonment of the former and the assassination of the latter; their life purpose remained unfulfilled.

Were Nelson Mandela and the Rev. Martin Luther King Jr. great leaders? Or were the times, the circumstances under which their leadership occurred extra-ordinary? What is the hallmark of a great leader, and who can generally be considered, especially from the perspective of politics, to have earned this distinction? Besides broad agreement that they were impactful in their nations, there are obvious markers recognizing them as transformational figures. This research, half a century after one of the series of major philosophical, moral and political transformations in India, South Africa and the United States, contemplates the leadership of Nelson Mandela, a founding member and past chairman of the African National Congress (ANC) and that of Martin Luther King Jr., Civil Rights leader who a year before Mandela's jailing, led a Million Man March on Washington and was killed four years after the landmark Civil Rights Act of 1964 passed.

There is no shortage of types of leadership that span the social, political and corporate spectrum; from transactional, to laissez-fair, to transformational to evolutionary - the list is quite expansive. Souller identifies 34 different public leadership behaviors, including setting the vision and staying focused, organizing, planning and giving power to others, ideation, problem solving and decisionmaking, executing, group building and maintenance. Each of these categories has several subcategories or manifestations of the leadership that can be easily and plausibly claimed by any leader even absent proof. Through history, some leaders have stood out above others and carved a niche through their actions, inaction, sacrifices, pronouncements and array of other attributes that they are undoubtedly, transformational, epoch-making, history-influencing leaders. Such individuals have been a voice of moral global conscience leadership. Some won the Nobel Peace Prize; others were assassinated, while others denigrated their achievements over time.

Martin Luther King Jr. and Nelson Rolihlahla Mandela are some of the best known, perhaps well-regarded leaders in history, although hindsight often reminds us of their failings as individuals. As political and moral leaders, they adorn history with sacrifices and actions that improved lives for millions of their fellow citizens, whether it was fighting to end racism or apartheid's colorism. They joined such other luminaries as Henri Dunant, Theodore Roosevelt, Woodrow Wilson, Jane Addams, Ralph Bunche, and George Marshall; also, their contemporaries such as Albert Luthuli, Mother Teresa, UNHCR, Desmond Tutu, Dalai Lama, Aung San Suu Kyi, Kofi Annan and Wangari Maathai as recipients of the Nobel Peace Prize.

This research especially examines the leadership circumstances, philosophies, issues, and accomplishments of the late the Rev. Dr. Martin Luther King Jr., and the late Nelson Mandela, in the context of political leadership. It interrogates their success, and the outcome in societies they advocated for, especially in the years following their leadership. The research argues that the transformative nature of MLK's leadership, the uniqueness of the time period and societal issues that propelled him to leadership, combined to make him the kind of once-in-a-lifetime unrivaled, righteous, grounded and transformative leader. For Mandela, the research points to four key issues that cemented his transformational leadership: i) the unique nature and near- intractability of the issues that facilitated, even explained his rise to prominence and his subsequent incarceration for life, ii) his ability to unify South Africa and for the country to avoid degenerating into racial war or ethnic conflict as was the case in many other African countries, or economic mismanagement such as Zimbabwe or Uganda in the 1970's; iii) reconciliation between the white and black South Africans, iii) his willingness to relinquish presidential power after only one term and iv) his modesty, shunning self-enrichment, self-promotion and inexplicable accumulation of wealth that has been part of the story of other African countries truly set him apart from most other leaders.

\section{Theories on (African) Leadership}

Is there such thing as African leadership? Is there a type of leadership specific to African leaders that can illuminate the African experiences in the colonization, independence, and postindependence periods? Scholarship on leadership does not make clear whether leadership is 
universal, or whether there are differences in the nature and definition of leadership based, for example, on geographic boundaries. As such, the concept of African leadership may refer to actions geared towards changing events on the African continent rather than qualities only found in leaders in African countries. However, a survey of literature appears to suggest that, for example, there is such a field as "African leadership", but omits the markers specific to African leadership. Is leadership universal, or could one argue for American leadership, and if so, what are the markers?

Notwithstanding these musings, scholarship points to the dearth of African leadership, or to negative connotations surrounding African leader(s)hip in majority of existing literature. Rotberg argues that "Africa has long been saddled with poor, even malevolent, leadership: predatory kleptocrats, military-installed autocrats, economic illiterates, and puffed-up posturers" (2006: 34). Ebiakor laments that Africa's leaders "have continued to flounder in mediocrity. For instance, it has become normal practice for African leaders to enrich themselves with little or no attention to the socioeconomic and political malaise facing their fellow citizens" (2004: 402). Gramby-Sobukwe notes the dissociation between African leaders and their citizenry, arguing that "since independence, African leaders and citizens have been at odds. Thirty years of neocolonial domination created authoritarian states and dictators who thrive in a climate of corruption and militarization. They sustain a political culture characterized by murder, tyranny, and dehumanization" (2005: 781).

The foregoing does not show particularity of African leadership; merely that those in positions of leadership do not always lead in the public interest. It is reflective of the overall difficulty that Lofchie identified in African politics; "African politics has always presented a special challenge and a special problem to political scientists, namely to develop a theory which would make sense of a vast, inchoate, and unfamiliar body of material" (1968: 3). Lofchie's point is illuminated by Swart, Van Wyck and Botha who write that "most leadership theory emanates from the United States, not even the "west" and approximately 98 percent of existing research-based knowledge about leadership is based on US leaders and managers" (2014: 661). On African leadership, they observe that "there appears to be scant reference to African leaders in the examples discussed" (2014: 662), except for Nelson Mandela who "frequently features as an example of charismatic and/or servant leadership" (2014: 662). Nkomo (2011) concurs with this view, writing that "Africa was all but invisible in the mainstream leadership and management literature" (366), further observing that even where different interpretations have occurred, they have largely preserved the western orientation of the understanding of leadership.

On Africa's leadership, Afegbua and Adejuwon observe that "leadership is one of the most observed and least understood phenomena on earth" (2012: 141). They note that in Africa, it has been associated with the need to solve the persistent social, political, economic, ethnic, communal and religious crises. Vogt articulates a history of leadership in which he surmises that "leadership may have evolved in small steps from a rather crude device for synchronizing the activities of simple organisms to complex structures able to coordinate the activities of millions of individuals dispersed across space and time" (2012: 143). Vogt notes the origins of evolutionary leadership theory is Darwin's voyage on the HMS Beagle, and the finding that "different species were beautifully adapted to their environments" (2012: 143) can be leveraged to understand how leader(ship) adapts and/or changes to resolve contentious circumstances and bring about desired change.

Bolden and Kirk note the contestation around leadership, but they identify four primary (broad) categories of leadership. These are first, existentialist theories - pitting leaders against followers and include situational, contingency and transformational leadership approaches. Good leadership, they argue, "is represented as either residing in the personal qualities of the leader, the behaviours they enact and/or the functions they perform" (2009: 70). Secondly, rational theories hold that "leadership resides not within leaders themselves but in their relationship with others" (Bolden \& Kirk 2009: 70). Leadership is thus seen as recognizing "the contribution of a wide range of actors as well as contextual and systemic factors" (Bolden \& Kirk 2009: 70).

Thirdly, critical theories "take a more skeptical perspective on leadership by exposing the underlying dynamics of power and politics within organizations" (Bolden \& Kirk 2009: 70). In the context of organizations that perhaps do not have the space to exist legally, constraints may present 
in considering leadership approaches in this context. Finally, Bolden and Kirk's fourth approach is a constructionist perspective where leadership "is utilized to construct shared meanings that enable people to make sense of their predicament" (Bolden \& Kirk 2009: 71). Ultimately, leadership is the ability of a leader to "influence followers to make self-sacrifices, commit to difficult objectives, and achieve much more than was initially expected" (Yukl 1999: 285) or can be achieved individually.

Although there is no compelling evidence or research -due to leadership studies primary focus on the west - of differences between leaders, based on their racial/ethnic origin, this research looks at the issue of leadership based on the definition of being able to influence people to take collective actions to improve their welfare, as a group, rather than individually. Since the object of this research is the question of MLK's and Mandela's successes, their leadership on two different continents, both tackling the prescient issues of their time and simultaneously confronting national, regional and global systems that most adamantly opposed their pursuit for change, this research will focus more on the personalities and circumstances both leaders were faced with, and then proceed to articulate the uniqueness and transformation the leaders produced, and non-replication thereof.

\section{The Africa(n)/American Condition: transformative issues or leaders?}

Did the conditions that were experienced by African Americans and their African brethren (racial segregation, colonialism and apartheid respectively) propagate the great leaders? Or were the issues so significant that anyone who took them on was destined to eventually become great leader? Across the continent, Pan-Africanists such as Jomo Kenyatta, Kwame Nkrumah, Kenneth Kaunda, Walter Sisulu, Patrice Lumumba and Julius Nyerere have long been revered as 'founding fathers' of their countries, of Pan-Africanism, and generally as great leaders. But given the conditions under which their leadership manifested, the incidental, rather than purposive nature of leaders' elevation was mostly the second act. Opposition to colonialism started as soon as the 1885 Berlin Conference concluded and European powers began carving and 'effectively occupying' new colonies. Some of the late-stage resistance leaders later became presidents and Prime Ministers in their liberated nations, despite some having served the very colonial powers they were replacing. An example of this was Félix Houphouët-Boigny, a Deputy in the French Parliament before becoming the new president of Côte d'Ivoire; he owed his rise to opposing communists and working with the French.

There were stark differences between the conduct of leaders in the pre-independence and postindependence periods; their leadership styles also differed, in part because of the issues that they faced and tools available to them. This gives rise to the view that in most cases, the issues were so great that they defined the role that the leaders stepped into. In the case of Mandela, the pre-and postindependence actions aligned to produce a transformative leader. It is perhaps not possible to make a similar argument for Martin Luther King; his death in 1968 does not lend the situation to similar analysis, although his transformative leadership is widely acknowledged. Given the impact of the work that he did with the civil rights movement, one wonders whether King might have ultimately sought political office in part to leverage his fame and accomplishments as a platform to accomplish the goals he set out. It is possible that the perception of his transformative leadership was in not seeking political office, thereby retaining ideological purity. On the other hand, because he was ultimately assassinated without completing the work of the civil rights movement, his stock might have risen higher due to his assassination.

\section{Colonialism in Africa and Apartheid in South Africa}

Nineteenth and early $20^{\text {th }}$ Century Africa was saw intense competition among foreign powers, for land, labor and natural resources, through colonization. De Alva defines colonization as deriving from the word colonus: tiller, farmer, cultivator and latter settler in a new (formerly uncultivated country)" (1995: 264). Explanations of European involvement in Africa range from overt 'colonization' to the more impactful 'civilization' to 'Christianization;' it has also been argued that the colonial experiment stemmed from Bismarck's appeasement of European powers in the post-1871 FrancoPrussian War, while others note that the second phase of Industrialization more readily supports the view of these actions as overt mercantilist imperialism. Explanation on the explosion of imperialism 
ranged from "intensity of competition for potential markets [that] led the competitors to exclude all rivals from potential colonial markets" (Wilson 1975: 72), necessitating territorial occupation, to Lenin's "theory of imperialism as a function of finance capital" (Wilson 1975: 72). It was also "economic exploitation" (Ahluwalia 2001:4) and contributed significantly to the rapid economic development in Europe and underdevelopment in the colonies. "The colonies supplied labor, raw materials and markets on which Europe came to depend" (Gosden 2004: 8) while exercising domination over locals (Hales 2006).

Once Africa's partition was complete, administering the colonies took different approaches, ranging from assimilation to indirect rule, driven by insufficient manpower and need to suppress anti-colonial sentiment. Different types of colonies flourished; the Unrepresented Nations and Peoples Organization (UNPO) identifies three types of colonies: settlement colonies, exploitation colonies and hybrid colonies. Settlement colonies, where "metropolitan settlers gradually ceased to identify with their metropolitan state and assumed an identity of their own, distinct from both the state they had left and the 'new world' as they found it upon their arrival" (1998: 221) included New Zealand, South Africa and Southern Rhodesia. Exploitation colonies "were established by private companies such as [the Dutch East Indies Company] DEIC in Indonesia and the BEIC in India" (1998: 223). The major feature of these colonies was that "the initial settlers were traders, who travelled back and forth between their home countries and the colonies. They rarely settled down permanently. In most cases the national governments of these entrepreneurs did not get involved in the colonization process until a substantial metropolitan presence had been established" (1998: 223). Finally, Hybrid colonies featured both types of settlements, e.g. Algeria: "some colonies manifested both elements or gradually changed from exploitation colonies to settlement colonies" (1998: 224).

South Africa was remarkably unlucky, suffering both colonialism and apartheid. Generally, colonialism dispossessed the majority African populations of land and only provided such access to education, economic opportunity, employment and property to the extent that these served as a source of revenue and coercion (hut and poll taxes requiring participation in the new economy), in South Africa's apartheid system, racial segregation was legislated and featured double dispossession: of land and ability to participate in politics and government, where to settle or live (shanty - towns and Bantustans), and generally, no redress mechanisms. Officially, South Africa was colonized by the English and the Dutch in the 17 $7^{\text {th }}$ Century (Hummel 2011: 4). In 1910, "the British formed the Union of South Africa as a dominion in the British Commonwealth" (Mwakikagile 2009: 54; Worger, Clark \& Alpers 2010: 32). From the very beginning of the Union, concerted efforts to separate the white minority from the black Africans ensued, with a belief that "Africans in their separate nations will obtain independent spheres in which they can prevail, make policy and modernize" (Butler, Rotberg and Adams 1977: 220). New African nations within South Africa were expected to follow the example of Transkei and constitute themselves as majority black spaces.

Apartheid "was a system of racial separation which dominated the Republic of South Africa from 1948 until 1993. Apartheid is an Afrikaans word meaning 'separateness'" (Hummel 2011: 4; and Downing 2004: 14). First instituted legislatively in 1948, the goal of apartheid was to separate the different races, with each having control over territory and population, but with the government run by the Afrikaner National Party (Downing 2004: 14). Practically, "the mechanisms of apartheid were set in place long before 1948...under apartheid, various races were separated into different regions and discrimination against people of color was not only acceptable, but legally entrenched, with whites having priority housing, jobs, education and political power" (Hummel 2011: 4). In his justification for this discriminatory policy Frederick W. de Klerk noted: "there were a number of motivations for apartheid, some of them selfish, some idealistic; some admitted, some unspoken. Foremost among these was our belief that without apartheid our people would be swamped by the vast black majority" (Downing 2004: 15).

Protest against the 1910 establishment of the Union of South Africa with practical separation based on race - effectively, racial segregation - began as soon as 1913. Worger, Clark and Alpers note that "the Natives Land Act of 1913...set up the mechanism to allocate land in South Africa on the basis of race" (2010: 31). Ninety three percent of the land was allocated to whites (20 percent of the 
population) and the rest - 7 percent - went to the 80 percent black population (2010: 31$)$. It was against this backdrop, two years before Nelson Mandela was born, that the South African Native National Congress (SANNC) - later abbreviated as ANC - was founded. In 1916, SANNC met in Pietermaritzburg in Natal, the very site of the establishment of the Union of South Africa with its future policy of apartheid formally instituted in 1948 by the National Party. The SANCC, which would define Mandela's life's struggle, had begun to fight for an end to the segregation.

\section{US racial segregation: the vestiges of slavery}

While the scramble for colonies was tearing Africa apart, the United States was going through its own torturous change: winding down institutional and legalized slavery. The 1862 Emancipation Proclamation and the subsequent Thirteenth Amendment effectively ended slavery, but ushered in a 100-year period when African Americans were segregated and treated as second-class citizens, akin to apartheid South Africa. Slavery as an issue had confronted and confounded the United States since its founding, and later formed the basis of a full-blown civil war. Corlett, by focusing on the structures of government at federal and state levels and their complicity in facilitating slavery, argues that the United States was an " an evil empire, an outlaw society" (2010: 16), in addition to the idea that its greatest evils have, to date, not been addressed or rectified (2010). Granted, as early as the Continental Congress, there were attempts to resolve the question of slavery, culminating in recognition of three groups of persons: 'free persons, Indians not taxed and all other persons' thus creating the 'threefifths compromise' with reference to the personhood of slaves.

Scholars hold that while the initiative to end slavery had taken place every step of the way through slavery's existence, signing of the Emancipation Proclamation in 1862 and the passing of the Thirteenth Amendment in 1865 were especially instrumental in ending slavery (Woog 2009: 1; Guelzo 2004: np; Holzer, Medford and Williams 2006: xiii-xiv; Hossell 2006: 8-10). As the Emancipation Proclamation took effect on $1^{\text {st }}$ January 1863, there was celebration and trepidation almost in equal measure; Frederick Douglass expressed that "we shout for joy that we live to recall this righteous moment ... freedom toe [sic] the slave will come peace and safety to your country" (Hossell 2006: 32) while "the cities of Washington, DC., Buffalo and New York greeted the news with 100-gun salutes" (2006: 33). Debates abound, on whether the Emancipation Proclamation issued from Lincoln's aversion to slavery and the view that "slavery is founded on the selfishness of man's nature" (Woog 2009: 2) or whether it was more of a necessary war measure with heavenly sanction, where "God had decided the question [of slavery] in favor of the slaves" (Masur 2012: 14).

The immediate task after the events surrounding the end of slavery was the question of what rights the newly freed slaves had. Indeed, scholars (for example, Franklin and Fitzgerald 2013: 78) note that the former confederate states passed legislation to disenfranchise blacks despite the federal Reconstruction Acts and supervision by former Union officers. Reconstruction Acts found little to no support in the South especially among former Confederate slave-owners, there were allegations blacks were unable to do more than "carry[ing] a ballot to the place where they are directed to deposit it", that allowing blacks to vote would erode democracy and thus, measures to forestall any significant voting by blacks gained support including by the President (Franklin 1998: 74).

Despite the challenges faced by the newly enfranchised African Americans, over time, some progress ensued. Perman and Taylor write that "when slavery was abolished, about 90 percent of the population was illiterate; by 1880 the rate of black illiteracy had been reduced to 70 percent, and by 1900 to less than 50 percent" (2011: 11), a 200 percent increase over 15 years and 400 percent over 35 years (Perman and Taylor 2011). Other positive outcomes included family reunification and solidification through "remarkable efforts to locate loved ones from whom they had been separated under slavery" (Foner and Mahoney 1997: 39) and the development of support institutions, in part because "they had been excluded from a role in church governance and often required to sit in the back pews during services" (Foner and Mahoney 1997: 39).

McNamara, Tempenis and Walton add that "the period following Reconstruction in the South was characterized by a general increase in anti-Black hostility: the separate but equal distinctions in public institutions and a reintroduction of anti-interracial marriage legislation" (1999: 30), with 30 
states subsequently prohibiting marriages between Whites and Blacks (1999: 31). This trend would continue throughout the first half of the $20^{\text {th }}$ Century, although some African Americans participated in some aspects of ordinary American life. Where they did, discrimination was rife, despite attempts at appearances to the contrary especially to the outside world. For example, in 1895, Atlanta's exposition organizers wanted "to demonstrate the racial tolerance of the region...invited Booker $\mathrm{T}$. Washington...to make a speech at the opening exercises" (Richardson 2007: 274). Wynn writes that "by 1920, the pattern of segregated life was well established, and Jim Crow laws ensured a separate existence for the races in most aspects of their lives" (2011: 11).

Even where national duty called Americans to stand as one, there was a conscious effort to separate the races. The Tuskegee Airmen story is well known, as is that of Bessie Coleman, the first African American woman to learn to fly (in France) (Francis and Caso 1997; Caver, Ennels and Haulman 2011). The Armed Forces were segregated, as were schools, colleges and most other public facets of American life. Life between the Civil War and the Civil Rights Act was characterized by race riots over jobs, housing and transport often without any re/action on the part of the authorities (Wynn 2011), vigilante justice from mobs and hate groups such as the Klu Klux Klan; these acts included castration, lynching and hanging (Rucker and Upton 2007: 90), exclusion from voter rolls including application of "voter suppression devices" (Davidson and Grofman 1994: 279). Other ways in which African Americans were targeted included the Tuskegee Syphilis Study, a medical experiment by government doctors on African American men (Gray 2013: 48-9).

It is into these conditions that Rev. Martin Luther King Jr., stepped as he began his ministry as a Baptist preacher. In fighting for equal rights, MLK was fighting the vestiges and effects of the "a system of labor, a form of race relations and the foundation of a distinctive regional ruling class" (Foner and Mahoney 1997: 37). Eerily, the racial segregation that was occurring in the United States was similar in almost every aspect to the racial segregation (apartheid) that was going on in South Africa. Perhaps it was inevitable then, that these conditions would give rise to two of $20^{\text {th }}$ Century's most charismatic, transformative leaders, two continents apart; a struggle aided in part by other global events with national and international consequences. Some of these included the aftermath of World War II, the rise of two centers of global dominance (US and USSR) and the decline of colonialism. While events such as the inability of African diplomats to find housing and other amenities in the United States based on their color (and the subsequent use of discrimination as propaganda against the US by the Soviet Union) hastened the changes in attitudes towards the issue of civil rights, it is also clear that leaders such as Martin Luther King were extremely important in changing the overall conditions experienced by African Americans in the United States (Norton, Kamensky, Sheriff, Blight and Chudakoff, 718-720).

\section{Transformational leaders resolving extraordinary challenges}

While tomes may be written about leadership theories, about charisma and leadership, and about what sets leaders such as MLK and Mandela apart from other African independence leaders, current and past crops of African American leaders, ultimately, some of the traits were personal, unique to the leaders themselves, while some were driven by the intersection between charisma, personality, the end-goal, the circumstances and others' actions that elevated the consideration accorded to both. Granted, racial segregation in the US and colonialism / Apartheid in South Africa were some of the more unusual events in history, their resolution had as much to do with the leaders as with external factors such as the Cold War and implications for race inequality on US diplomatic relations coupled with changing attitudes towards equality; and the alienation of South Africa from participation in global commerce, regional associations and international bodies coupled with strikes, sabotage, support all over Africa for freedom fighters and internal dissent. One might surmise therefore, that for South Africa and the United States, majority of the $20^{\text {th }}$ Century was unique, and the challenges that minority populations faced - the issues - necessitated the rise of charismatic leaders.

South Africa's peaceful transition for apartheid nation to Rainbow Nation, per Charteris-Black, "can be attributed directly to his leadership...a defining characteristic of transformational leadership 
is the effect that a leader has on followers, then, undeniably, Nelson Mandela had profound influence - both on followers and on representatives of the apartheid system" (2007: 80). This reflected many years of calm and self-composure, learnt under his long incarceration. Reflecting on the incarceration, Mandela determined that "they could take everything from me except my mind and heart. They could not take those things. Those things I still had control over. And I decided not to give them away" (Mandela, foreword). Mandela himself recognized the uniqueness of the circumstances that thrust him upon the world stage. "I was not a Messiah, but an ordinary man who had become a leader because of extraordinary circumstances" (Leider 2003: 11). Unburdened and after serving his country as prisoner-turned-president, Mandela lived to see the fruits of his protests, beginnings of a legacy often considered in Washingtonian terms, and towards the end of his presidency, expressed contentment saying: "I want to sleep for eternity with a broad smile on my face. I want those who remain behind to say, this man has done his duty" (2003: 12).

Mandela's life was not only defined by the choices that he made, for example, starting a law practice with Oliver Tambo to provide free or low-cost representation to Black South Africans (Sosik 2006: 151), but also by the strategies that he sometimes employed to fight apartheid. For example, "in 1952, Mandela created the Campaign for the Defiance of Unjust (and oppressive) Laws" (Lowham 2007: 21), whose goal was "to disobey these laws, suffering arrests, assault and penalty if needed, without violence. The method was to send in groups of carefully trained 'volunteers' to disobey publicly (Okoth 2006: 176). This campaign resembled to the protests that would later take place in the United States, including the Montgomery Bus boycott and the lunch counter sit-ins. The campaign had limited progress other than illuminate injustices and increase ANC membership; thereafter, Mandela began to explore militarism, resulting in his life sentence.

Mandela considered the utility of other approaches - as is evident with the Campaign for Defiance of Unjust Laws; he explained the influence of Gandhi's satyagrahai principle, which was ultimately abandoned as the ANC interacted with other groups, received training and funding to wage a militant campaign. Kallen writes that per Mandela:

"if a particular method or tactic enabled us to defeat the enemy, then it should be used. In this case, the state was far more powerful than we, and any attempts at violence by us would be devastatingly crushed. This made nonviolence a practical necessity rather than an option...I called for nonviolent protest as long as it was effective" (2011: 73).

Even during his incarceration, Mandela continued to be the focus of the injustice of the apartheid system; his association with ANC and practical leadership passed on to others in the organization, yet his incarceration shone the light on the conditions in South Africa, the injustice of the apartheid system and gave impetus to global resistance. Mandela's choices after his release on February 11, 1990 cemented his legacy as a transformational leader; perhaps his greatest moment came when faced with the question of what to do about those who had presided over his incarceration:

"He did not seek vengeance against the former government officials that had unjustly treated him...instead, Mandela initiated a tempered response of forgiveness and reconciliation...offered truth-telling conciliatory trials where pardons were given out in return for telling the true story of what had happened to his people and their country during the days of apartheid" (2011: 152).

Thus, while the circumstances that defined Mandela's life while in themselves exceptional, his reaction to them, the grace he showed under exceedingly difficult circumstances "create(s) significant change in the life of people and organizations" (Griffin and Boone 2014: 204). In his case, his incarceration provided impetus, a protest symbol to the protest movement, and provided a protest symbol and his embodiment of what was wrong with apartheid. His eventual idolization was supplanted by the notion that "he rarely used the word "I" in his presentations and he stated repeatedly that he 'was simply a servant of the public', someone who sought greater good from his years in prison instead of personal revenge or benefit" (2014: 204). One concludes then, that although some of his earlier activities may have taken on a militant, destructive bent, in his later years, Nelson Mandela attracted the admiration of friend and foe alike. 
Can the same be said of Martin Luther King? How did he deal with the extraordinary circumstances of the policies of racial segregation? Did he demonstrate charismatic, transformative leadership, or did he ride the coattails of the Montgomery Bus boycott, the Memphis sanitation workers' strike, the North Carolina lunch sit-ins and other similar events? The post-Reconstruction southern region of the United States was clearly a hostile, unfriendly place, racially segregated in every aspect - from housing to education to work - and where a man of color could reasonably expect a lynching on trumped-up charges and mob justice rather quickly.

Scholarship argues on both sides of the issue. McElrath, for example, writes that "Martin Luther King is often categorized as a leader for blacks, but this is far from the truth. King was a moral leader...his leadership was two-fold: he was able to mobilize blacks, while at the same time appealing to the consciences of many whites" (2008: 276). Philips concurs: "clearly, Martin Luther King, Jr., fit the profile of a high-energy, action-oriented leader. His mission was to institute massive transformation in the social order of America" (2001: 110) by employing strategies he believed would be effective, which included placing events in context (of a broader struggle and as a continuation of the Civil War), appealing to ethics and morality and dissemination of facts and advocating for initiatives. Just as he expressed preference for peaceful protests, and chose strategies supporters and sympathizers could relate to, King found buy-in by developing coalitions and campaigns such as the Poor People's Campaign, seeking "to turn the civil rights movement toward an economic agenda" (Honey 1997: 168) broadening the movement and thus "bring together the economic grievances of poor whites, blacks, and other people of color" (1997: 168).

Not everyone agrees that King was a transformative leader, well beloved, with a coherent strategy and charisma that drew most to the cause, questions that extend beyond his personal relationships and conduct. Indeed, some question whether King's contribution was as salient as the driving force of the issues themselves. Dym, Egmont and Watkins, for example, write that:

"the Civil Rights Movement was attributed to the leadership of Martin Luther King...and others with considerable oratorical flair. Yet much of the grassroots leadership came from virtually unsung black women whose years of church and community participation had positioned them and honed their skills perfectly for organizing local political campaigns. They were the right people, at the right time, and in the right place, to lead one of the crucial phases of the movement" (2011: 134).

Other scholars have been critical of King and particularly his leadership of the Southern Christian Leadership Conference (SCLC). Fairclough writes that "the sit-ins and the Freedom Rides not only exposed SCLC's organizational weaknesses, they also cast doubt upon King's own qualities of leadership" (2001: 57) particularly over King's perceived ambivalence to lead lunch counter protests. Fairclough points out that "his failure to go to jail brought his tactical judgment - and even his personal integrity - into question" (2001: 58). It is unclear that these actions would necessarily have brought about different, or significantly more immediate results.

King himself experienced personal crises related to the movement; Ansbro writes that "in the second month of the [Montgomery Bus] boycott, King experienced a crisis in which he was losing confidence in his capacity to continue as the leader" (2000: xix) until he drew upon his religious and inner strength to continue. In time, he adopted strategies that eventually saw him arrested and thrown into a solitary cell for breaking unjust laws while obeying just laws, during the campaign to desegregate Birmingham, Alabama (Hamilton 2002: 233). However, his contributions are viewed, Martin Luther King Jr.'s actions had an impact on, and helped coalesce diverse coalitions to support desegregation of the South, and led to the Civil Rights Act of 1964.

\section{League of extraordinary gentlemen: King and Mandela}

That they were instrumental in, or largely associated with pursuing courses of actions that other leaders, particularly in the African and African American communities, did not appear to carry out as well, is one of the factors that illuminate Martin Luther King and Nelson Mandela as iconic leaders of their communities and time. By choosing to pursue a mix of peaceful, disobedient and often militant courses of action, by coalescing around moral, ethical, social and economic issues affecting 
their communities and taking action that often endangered them greatly, these two transformational leaders entered the annals of history as transformative individuals. Tragically, Martin Luther King's dream was cut short by an assassin's bullet in 1968, long before the racial, social and economic conditions completely transformed.

Mandela and King's leadership and accomplishments stand in contrast to other "black" leaders, some of them erstwhile Pan-Africanists such as Nyerere, Nkrumah, Kenyatta, and Kaunda. Much of the differences between them and Mandela-King can be attributed not to the role that they played in the independence, but to their post-independence actions. For example, Kenyatta ruled Kenya from independence in 1963 until his death in 1978; in the fifteen years, he managed to suppress opposition parties, turn the country into a de jure one-party state, and purportedly accumulated more than 500,000 acres and over $\$ 500$ million which was passed on to the current custodian, Uhuru Kenyatta, Kenya's fourth president. Kenyatta's widow, Mama Ngina Kenyatta was reportedly worth $\$ 1$ billion in 2014.

While not all the leaders engaged in wholesale personal enrichment, even such Pan-Africanists such as Nyerere quickly sacrificed the democratic ideals in favor of one-party rule under the guise of national unity. Nyerere led Tanzania from independence in 1961, retiring in 1985; clearly not the most illustrative democrat. In 1966, Kwame Nkrumah was overthrown by a military coup d'état, accused of dictatorial tendencies (and coddling up to the Warsaw Pact and China). Kenneth Kaunda ruled Zambia from 1964 until he was forced out after the first multi-party democratic elections in 1991, hardly the picture of democratic governance. Even Robert Mugabe, once an iconic freedom fighter in Southern Rhodesia, has been in power for 35 years.

Contrarily, Nelson Mandela, after guiding South Africa from the Apartheid Nation to the Rainbow Nation, and after only one term as president, retired in 1999. After his death, the family reported that Mandela was worth $\$ 4$ million (BBC News Africa). Other reports indicated that during the life of his presidency, Mandela donated 1/3 of his salary to South African children's charities (Celebrity Net Worth, n.d.) As other African leaders go, this was somewhat highly unusual - one could almost imagine Mandela was a poor president. Martin Luther King was similarly "poor", worth a little more than $\$ 54,000$ - most of it from the Nobel Peace Prize money (Perryman 2011).

There are characteristics, actions and traits that, taken together, set King and Mandela apart from other leaders of their time. In contrast with modern civil-rights leaders, Martin Luther King was almost poor. Unlike most independence era presidents, Mandela did not enrich himself at the expense of his countrymen, was never accused of corruption or raiding state coffers, and stepped down after one term as president, an exceedingly rare, almost unheard-of proposition in Africa. It is plausible therefore, to place them in a category apart from other African and African American leaders, a category that managed to accomplish leadership that has not been replicated since.

The early-to-late $20^{\text {th }}$ Century circumstances that both faced were as important as the actions that they took to deal with them; institutional racism required transformative leadership provided by Martin Luther King. Apartheid coupled with colonialism required transformational leadership such as provided by Mandela. Perhaps by their charismatic, transformational leadership, they rendered the post-racial and post-colonial societies incapable of matching the leadership they demonstrated. It is plausible though, that Martin Luther King and Nelson Mandela were transformational leaders, that they had providence's unique opportunity to tackle once-in-a-generation issues, and only they were suitably placed to write the history with the brush-strokes that have rendered them immortalized in the annals of transformational and moral leadership for all time, so that the US has not found another such leader, while in Africa, Mandela occupies a lofty perch without equal.

"I have cherished the ideal of a democratic and free society in which all persons will live together in harmony and with equal opportunities. It is an ideal for which I hope to live for and to see realised. But, My Lord, if it needs be, it is an ideal for which I am prepared to die." 
"I have a dream that my four little children will one day live in a nation where they will not be judged by the color of their skin but by the content of their character."

Rev. Martin Luther King Jr., 1963

Conflicts of Interest: The author declares no conflict of interest.

\section{References}

Afegbua: Salami and Kehinde David Adejuwon. "The Challenges of Leadership and Governance in Africa." International Journal of Academic Research in Business and Social Sciences Vol. 2, No. 9 (9/ 2012): 141-157. URL: $\underline{\text { http://www.hrmars.com/admin/pics/1105.pdf }}$

Africa Ranking. "Richest Presidents in Africa 2015." (Web). http://www.africaranking.com/richest-presidents-inafrica/3/

Ahluwalia, D. Pal S. Politics and Post-colonial Theory: African Inflections. London: Routledge, 2001. (Print).

Ansbro, John J. Martin Luther King, Jr.: Nonviolent Strategies and Tactics for Social Change. Lanham, MD: First Madison Books, 2000 (Print).

BBC News Africa. "Nelson Mandela left \$4m estate." BBC News. (Web). 3 $3^{\text {rd }}$ February 2004. http://www.bbc.com/news/world-africa-26014868

Bolden, Richard and Philip Kirk. "African Leadership Surfacing New Understandings through Leadership Development," International Journal of Cross-Cultural Management, Vol. 9, No. 1 (2009): 69-86. https://doi.org/10.1177/1470595808101156

Business Daily. Mama Ngina, Biwott in Africa billionaires list. (Web). Accessed from:

http://www.businessdailyafrica.com/Corporate-News/Mama-Ngina-and-Biwott-in-Africa-

billionaires-list/-/539550/2024388/-/guhy65/-/index.html on 2/4/2014

Butler, Jeffrey, Robert I. Rotberg and John Adams. The Black Homelands of South Africa: The Political and Economic Development of Bophuthatswana and KwaZulu. Berkeley: University of California Press, 1977. (Print)

Caver, Joseph, Jerome A. Ennels, and Daniel Lee Haulman. The Tuskegee Airmen: An Illustrated History, 1939-1949. Montgomery: NewSouth Books, 2011. (Print).

Celebrity Networth. "Nelson Mandela Net Worth." (Web). http://www.celebritynetworth.com/richestpoliticians/presidents/nelson-mandela-net-worth/

Charteris-Black, Jonathan. The Communication of Leadership: The Design of Leadership Style. Oxon: Routledge, 2007. (Print).

Corlett, J. Angelo. Heirs of Oppression. Lanham: Rowman \& Littlefield, 2010. (Print).

Davidson, Chandler and Bernard Grofman. "The Voting Rights Act and the Second Reconstruction," in Chandler Davidson and Bernard Grofman, eds. Quiet Revolution in the South: The Impact of the Voting Rights Act, 1965-1990. Princeton, NJ: Princeton University Press, 1994. (Print).

de Alva, J. Jorge Klor. "The postcolonization of the (Latin) American Experience: A Reconsideration of 'Colonialism', 'Postcolonialism' and 'Mestizaje'. In Gyan Prakash, Ed. After Colonialism: Imperial Histories and Postcolonial Displacements. Princeton: Princeton University Press, 1995. (Print)

Downing, David. Apartheid in South Africa. Chicago, IL: Heinemann Library, 2004.

Duigan, Peter and L. H. Gann. "The pre-colonial economies of Sub-Saharan Africa." In Peter Duignan and L. H. Gan, Eds. Colonialism in Africa 1870-1960: Volume Four - The Economics of Colonialism. Cambridge: Cambridge University Press, 1975. (Print)

Dym, Barry, Susan Egmont and Laura Watkins. Managing Leadership Transition for Nonprofits: Passing the Torch to Sustain Organizational Excellence. Upper Saddle River: Pearson Education Inc., 2011. (Print) 
Feagin, Joe R. Racist America: Roots, Current Realities, and Future Reparations. Hoboken: Taylor and Francis, 2014 (eBook).

Eric Foner and Olivia Mahoney. America's Reconstruction: People and Politics After the Civil War. Baton Rouge: LSU Press, 1997. (Print).

Fairclough, Adam. To Redeem the Soul of America: The Southern Christian Leadership Conference E Martin Luther King, Jr. Athens, GA: The University of Georgia Press, 2001. (Print).

Francis, Charles E. and Adolph E. Caso. The Tuskegee Airmen: The Men who Changed a Nation. Boston: Branden Publishing Co, 1997. (Print).

Franklin, John Hope. Reconstruction after the Civil War. Chicago: The University of Chicago Press, 1994. (Print).

Franklin, John Hope and Michael W. Fitzgerald. Reconstruction after the Civil War, $3^{\text {rd }}$ Ed. Chicago: University of Chicago Press, 2013. (Print).

Gramby-Sobukwe, Sharon. "Africa and U.S. Foreign Policy: Contributions of the Diaspora to Democratic African Leadership." Journal of Black Studies, 35, No. 6 (Jul., 2005): 779-801. URL: http://www.jstor.org/stable/40034881.

Gray, Fred D. The Tuskegee Syphilis Study: An Insiders' Account of the Shocking Medical Experiment Conducted by Government Doctors against African American Men. Montgomery: NewSouth Books, 2013. (Print).

Griffin, Cindy and Jennifer Bone. Invitation to Human Communication. Boston: Wadsworth, 2014. (Print).

Gosden, Chris. Archaeology and Colonialism: Cultural Contact from 5000 BC to the Present. Cambridge: Cambridge University Press, 2004. (Print)

Guelzo, Allen C. Lincoln's Emancipation Proclamation: The End of Slavery in America. New York: Simon \& Schuster Paperbacks, 2004. (Print)

Hales, Jennifer. "An Anti-Colonial Critique of Research Methodology." In George Jerry Sefa Dei and A. Kempf, Eds. Anti-Colonialism and Education: The Politics of Resistance. Rotterdam: Sense Publishers, 2006. (Print)

Hamilton, Neil A. American Social Leaders and Activists. New York: American Social Leaders \& Activitists, 2002. (Print).

Holzer, Harold. The Emancipation Proclamation: Three Views (social, Political, Iconographic). Baton Rouge: Louisiana University Press, 2006. (Print)

Honey, Michael. "Martin Luther King, Jr., the crisis of the Black Working Class and the Memphis Sanitation Strike." In Robert H. Zieger, ed. Southern Labor in Transition, 1940-1995. Knoxville: The University of Tennessee Press, 1997. (Print)

Hossell, Karen Price. The Emancipation Proclamation. Chicago: Heinemann Library, 2006. (Print)

Hummel, Philip. My Life Growing Up White During Apartheid in South Africa. Bloomington: AuthorHouse, 2011. (Print).

Kallen, Stuart A. Open the Jail Doors - We Want to Enter: The Defiance Campaign against Apartheid Laws in South Africa, 1952. Minneapolis: Twenty-First Century Books, 2011. (Print).

Leider, Richard. "For the Sake of What." In Richard Strozzi-Heckle, Ed. Being Human at Work: Bringing Somatic Intelligence into Your Professional Life. Berkeley: North Atlantic Books, 2003. (Print).

Lofchie, Michael F. "Political Theory and African Politics." The Journal of Modern African Studies, Vol. 6, No. 1 (May, 1968): 3-15. URL: http://www.jstor.org/stable/158673.

Lowham, Elizabeth A. Too Many Cooks? Distributed Leadership in State Brownfields Remediation and Redevelopment Programs. Ann Arbor: Proquest, 2007. (E-resource)

Mandela, Nelson. Long Walk to Freedom: The Autobiography of Nelson Mandela. New York: Little, Brown \& Company (Back Bay Books), 1995. (Print). 
Masur, Louis P. Lincoln's Hundred Days: The Emancipation Proclamation and the War for the Union. Cambridge: The Belknap Press of Harvard University Press, 2012. (Print).

McElrath, Jessica. The Everything Martin Luther King, Jr. Book: The Struggle, The Dream. The Legacy. Avon: F+W Publications, 2008. (Print)

McNamara, Robert P., Maria Tempenis and Beth Walton. Crossing the Line: Interracial Couples in the South. Westport: Greenwood Publishing Group, Inc, 1999. (Print).

Mwakikagile, Godfrey. Africa after Independence: Realities of Nationhood. Dar Es Salaam: New Africa Press, 2009. (Print)

Nkomo, Stella M. "A postcolonial and anti-colonial reading of 'African' leadership and management in organization studies: tensions, contradictions and possibilities." Organization, 18 (3), (2011): 365-386. DOI: $10.1177 / 1350508411398731$

Norton, Mary Beth, Jane Kamensky, Carol Sheriff, David W. Blight, Howard Chudacoff, Fredrik Logevall, Beth Bailey and Debra Michals. A People and a Nation, Volume II: Since 1865, Brief Edition. Stamford: Cengage Learning, 2015. (Print)

Obiakor, Festus E. "Building Patriotic African Leadership through African-Centered Education." Journal of Black Studies, Vol. 34, No. 3 (Jan., 2004): 402-420. URL: http://www.jstor.org/stable/3180944

Okoth, Assa. A History of Africa: African nationalism and the de-colonisation process: 1915 - 1995. Kampala: EAEP, 2006. (Print).

Perman, Michael and Amy Murrell Taylor. Major Problems in the Civil War and Reconstruction: Documents and Essays. Boston: Wadsworth, 2011. (Print)

Perryman, Wayne. "Poor Dr. King \& Rich Civil Rights Leaders." The African Executive. (Web). http://www.africanexecutive.com/modules/magazine/articles.php?article=7700

Phillips, Donald T. Martin Luther King, Jr., on Leadership: Inspiration and Wisdom for Challenging Times. New York: Warner Books, 2001. (eBook).

Richardson, Heather Cox. West from Appomattox: The Reconstruction of America after the Civil War. Yale: Yale University Press, 2007. (Print)

Rotberg, Robert I. "Strengthening African Leadership: There Is Another Way." Foreign Affairs, Vol. 83, No. 4 (Jul. - Aug., 2004): 14-18. URL: http://www.jstor.org/stable/20034043

Rucker, Walter C. and James N. Upton, Eds. Encyclopedia of American Race Riots. Westport: Greenwood Press, 2007. (Print).

Sosik, John J. Leading with Character: Stories of Valor and Virtue and the Principles They Teach. Charlotte: Information Age Publishing, 2006. (Print).

Scouller, J. (2011). The Three Levels of Leadership: How to Develop Your Leadership Presence, Knowhow and Skill. Cirencester: Management Books, 2000. (Print)

Swart, Gerrie, Jo-Ansie Van Wyck and Maryke Botha. "African Political Leadership." In R. A. W. Rhodes and Paul 'T Hart, Eds. The Oxford Handbook of Political Leadership. Oxford: Oxford University Press, 2014. (Print)

Unrepresented Nations and Peoples Organization. UNPO yearbook. The Hague: Kluwer Law International, 1998. (Print)

van Vugt, Mark. "The Nature in Leadership: Evolutionary, Biological and Social Neuroscience Perspectives." In David V. Day and John Antonakis, Eds. The nature of leadership. Thousand Oaks: Sage Publications, 2012. (Print) 
Wilson, Charles. "The economic role and mainsprings of imperialism," In L. H. Gann, Peter Duignan and Victor Witter Turner. Colonialism in Africa 1870-1960: Volume 4 - The Economics of Colonialism. New York: Cambridge University Press, 1975. (Print).

Woog, Adam. The Emancipation Proclamation: Ending Slavery in America. New York: Infobase, 2009. (Print)

Worger, William H., Nancy L. Clark and Edward A. Alpers. Africa and the West: From colonialism to independence, 1875 to the present. New York: Oxford University Press, 2010. (Print)

Wynn, Neil A. The African American Experience during World War II. Lanham: Rowman \& Littlefield, 2011. (Print).

Yukl, Gary. "An Evaluation of Conceptual Weaknesses in Transformational and Charismatic Leadership Theories." Leadership Quarterly, 10, 2, (1999): 285-305. https://doi.org/10.1016/S1048-9843(99)00013-2

i The Merriam-Webster Online Dictionary defines satyagraha as pressure for social and political reform through friendly passive resistance practiced by M. K. Gandhi and his followers in India 